\title{
The Relationship Analysis between Government and Social Organization in Government Purchases of Services in the New Era
}

\author{
Yulong Wang \\ Social Work Research Center, South China University of Technology, Guangzhou 510641, China
}

Keywords: New Era, Government Purchases of Service, Relationship between Government and Society.

\begin{abstract}
Government purchase of services as a diversified way to provide social services, which has been raised to an important position in social development in the new era of our country, country has gradually opened the government purchases of services since 2014. Social organization as one of the important participants that government-oriented social services provided, how to build a harmonious relationship with the government will be an important issue. Learning from government and social relations established by Western society in the early days of the government purchase of services, but many contradictions and conflicts are exposed in the specific practice, such as non-separation between government and society, no lawful regulations and lack of trust, etc., this acclimatized phenomenon should be attributed to running-in reaction of western theory in the early days of localization. However, this contradiction and conflict between government and society will exist for a long time, but as far as the future development trend of government purchases of social services with Chinese characteristics, the regulations and mutual trust will be perfected and established in the development, and the dependence relations of social organization for the government will be strengthened.
\end{abstract}

\section{Introduction}

As a newly emerging governance tool, the government purchases of services from social organization has been widely used by many capitalist developed countries since the 1970s through the sweeping of global association revolution and revolution and cooperative governance. However, government purchases of services from social organization are still in the exploratory stage in China's new era, in practice, the prevalence of lack of legal protection, supervision and management is not enough, capital budget is unstable, purchase of service is small-scale, the purchase process is not standardized, responsibility becomes formalistic and other problems. As the carrier of public power, our government plays a central role in the governance field of public affairs for a long time. The government has not completely jumped out of the traditional system of "omnipotent government" in governance transition; there are the function transfers not in place, the power boundaries are not clear and so on; social organization as the carrier of social forces, the overall development is not perfect, the ability is to be improved, it is difficult to find a suitable positioning in cooperative relationship with highly unreasonable resource dependence, and achieve healthy development. A truly systematic, scientific, normative and effective government purchase of services from social organizations is far from established. The characteristics of relationship between government and society based on government purchase of services are analyzed in this paper currently, in order to provide some suggestions and reference for the long-term development of government purchases of services.

\section{Relationship Construction between Government and Social Organization in the Government Purchases of Services}

First, we need to clear the definition of government purchases of services. Government purchases of services are that government takes a certain amount of funds in budget involved in public social welfare, set a standard service evaluation system, under the premise of government and social organization' communication, consultation and cooperation, the service items were originally provided by the government directly which in order to improve people's daily life and promote the 
good development, and give the social organizations which provide public services to complete through open tender, directed commission and inviting bid form. At the same time, the government and the social organization signed a certain contract, in the case that legal protect the relationship between the two sides, according to the quality and quantity of services provided by the social organizations, the government pay the cost of services. This can be summarized as a "governmental funding, targeted purchase, contract management, cash evaluation" public service supply mode.

\section{Multiple Characteristics of Relationship between Government and Society in Government Purchases of Services in the New Era}

This idealized relationship between government and society has exposed many contradictions and conflicts in social practice of the new era:

(1) Non-separation between government and society, government-oriented, society comply, external promotion, internal cooperation

In the traditional social management mechanism, there is serious offside and misplaced phenomenon in the social function of the government, which makes the government play the policy maker, the practice organizer, the service provider and the referee of the problem and other contradictory roles meantime in the social construction. At present, the process of administrative system reform is slow in our country, the transform of government function is limited, the administrative simplification is not enough, and the role of unlimited government the system is still not completely changed, so it is difficult for social organizations to grasp the social construction resources and corresponding public power in the field of government purchases of services, and thus lack due development vitality, "high dependence and low autonomy" has become a significant feature of social organizations, the establishment of equal government and social cooperative relations still face multiple obstacles.

It is not difficult to find that China's government purchase of services is product that government-oriented, society comply, external promotion and internal cooperation, but lack more mature market economy environment and protection of the laws and regulations like West, besides, modern social organization system which is consistent with the social development trend has not yet been established, most social organizations are either relatively weak or weak influence; either its development is helped by governmental inclination, administrative color is more intense. Although theoretically, the government and the organizations that undertake public services should be independent and equal subject, the decision and executive functions are separate, each performs its own functions, but because the current power and resources are still firmly in the hands of the government, so the governmental strong domination and control, the weak compliance and attachment of social organizations, which inevitably show the "decentralization of society" more in name than in reality. Sometimes "decentralization" even show further penetration of government power, and it causes social organizations more and more depend on the government.

Therefore, it is difficult for the governmental and social relations to achieve the independence and equality emphasized by the contractual cooperation under the current government purchases of services policy, but in a non-reciprocal interactive state (including the non-reciprocal nature of rights and dependence degree), the transfer of government function is not sufficient, the main body of service is diversified, authority and responsibility of governmental and social relations are vague in the practice process and other phenomena, governmental and social relations need to be adjusted and reconstructed.

(2) No laws to abide by: the system construction space constraints and legislation stagnation

"No laws to abide by" or "legal vacuum" is another important feature of government purchases of services. Some scholars pointed out that in order to solve the existence of contradictions and conflicts in government purchases of services and traditional systems, it is necessary to add supporting construction from the system and regulations to achieve the feasibility and effectiveness of the purchases of services. To build a set of perfect system, especially improve the legal system, it is an 
important condition for the government purchases of services to run smoothly and develop steadily, and it is also the system guarantee of the division and cooperation of government and society. Throughout the smooth implementation of the government purchases of services policy in the western developed countries, Hong Kong and Taiwan, besides the good social organization system and the social environment, the most important thing is that the corresponding system construction, laws and regulations give vital guarantee.

However, in the current development process of China's government purchases of services policy, neither a clear content, purchase system with clear right and responsibility, and the corresponding financial system, nor to establish matching laws and regulations protection, the regulatory assessment mechanism also need to be further established and improved. Specifically, it mainly involved the following aspects: first is the lack of corresponding legal system protection, although the purchase scopes are set in the "Law of Government Purchase of PRC", including services, but the understanding of the service is limited to the service that government operation need, the public services that provided for the public are not included in the scope of government purchase; the second is that a unified and perfect government purchases of services system has not yet developed, only to put forward some guidance or request, for example, the Ministry of Civil Affairs and the Ministry of Finance in 2012 jointly issued "Guidance on the Government Purchasing Social Work Services" and so on, and there are big differences in purchase system content, procedures and standards in different regions, government purchase service system need to be into a unified system; third is the government purchasing funds failed to be integrated into the unified financial budget, it is not conducive to the audit and supervise, the stability of the purchasing funds is weak; fourth is the lack of effective supervision and evaluation mechanism, the monitoring that the government for service quality and performance are limited.

The lack of legal protection further leads to the lack of fundamental governance rules and mechanisms in the practice of government purchases of services, as well as a wider range of state governance and social governance field, which makes the rule of law and governance according to law particularly important. Social development and national construction call for the establishment of governing the country by law and rule of law in the new historical period.

(3) Lack of trust: lack of mutual trust between the government and society

Some scholars use the correlation theory of game theory to build the relationship matrix of trust between the government and society, it showed that the government and society two sides lack mutual trust mechanism in the construction of contractual relationship, and only a good competition and cooperation relationship is established based on relationship of mutual trust, and then the important role of social organizations can be played in the transform of government functions. Although actually in the early stage of the purchase service, the government and the social organization signed a project contract, the contractual relationship that two sides formed emphasize the independence and equality, mutual trust to a certain degree. However, because this kind of contractual relationship is only a seemingly independent and formal agreement, its binding force on the government is weak, the governments only intervene through the power and can make contractual relationship between government and social organizations deteriorate. There seems to be some difference in the development goals of the social organization and the governmental objectives from governmental operational logic, so the governments usually doubt the decentralization of resources and power into the social organization, if there is a large deviation between the two objectives, it may evolve into a risk or a crisis; at the same time, the government may also worry that social organizations master the public resources and power, and it will become an external force and difficult to control; in addition, the lower identity of services capacity of social organization is one of the reasons why governments lack trust for social organization.

Thus, there is lack of mutual trust in the interaction between government and society, coupled with the lack of communication platform, inclusion of interactive interface contains is not enough, and thus intensify the deviation of each other's goals and bias of understanding; this deviation and bias are the 
results that not independent and equal contractual relationship brought about, meanwhile conversely led to the dissolution and evolution of cooperative relations.

\section{Development Trend of the Relationships Characteristics between Government and Society in the New Era}

(1) Conflicts and contradictions of relationships between government and society will exist for a long time

Because the development of public utilities need to invest a lot of manpower, material and financial resources, and the government mainly directly responsible for the development of public utilities in our country, in the management of public utilities, the government undertake affairs that a large number of the market and society should bear, which causes the governmental functions offside, absent in some aspects or fields, the repeated construction of functional organs led to institutional expansion and staff increase, " supply staff" situation not only exist, but also "support affairs" situation, resulting in a serious waste of state funds, solving efficiency of social affairs is low; in order to meet the people's growing demand for social services, the government is bound to adjust the government functions, allow the third sector formed by social organizations with governments and enterprises form a "society-country-market" triple social service supply model, so that the three complement each other in function. Although the existence of social organizations can not only effectively avoid the impact of government failure and market failure, but the government purchases of services from social organization can also reduce service costs and improve service quality and efficiency, and thus meet the needs of people's livelihood, but limited transform of government functions and government-responsible positioning that social services provided makes the government cannot be fully decentralized to social organization, so the conflict and contradictions cannot be eliminated between government and social organizations in the short term, it is not easy to control in range that both side accept.

(2) The dependence relations of the social organization for the government will be strengthened and characterized

The government purchases of services from social organization are not accidental action, and it is a not temporary action. In order to achieve socialization of public services and optimization of effect, governments and social organizations should theoretically respect each other, negotiation dialogue and adhere to the principle of law, because only the full respect for the interests of all stakeholders and reservation of all parties, and then diversified public service subject and public service content, but the reality is to explore a social service supply system which is suitable for China's national conditions must choose localization development, China proposes government purchases of services from social organization should adhere to the "party leadership, government responsibility, social coordination, public participation, the protection of rule of law," basic principle is the result of social service localization. It can be clearly seen that dominant and cooperative relationship between government and society, this kind of dependence relations is suitable for the reality of China; therefore, supply mode of social service with Chinese characteristics must be strengthened in the in practice.

(3) Regulations and mutual trust will continue to improve and develop in the development

The government purchases of social services is still a new thing in the new era, although there are mature experience can be learned from West, but making it localized still need a long time. Therefore, various phenomenon or problems caused by imperfect laws and regulations will continue to be resolved in practice in the process of government purchases of social services. In this regard, first, local governments make system level of construction and norms for the problems arising in the local region, when the country succeed in a wider range, then the relevant regulations and systems are bound to gradually rise to the rules or law, it is followed and implemented by the relevant institutions and departments of the national social service field finally.

The mutual trust between government and social organization needs to be established in practice. First of all, social organizations should recognize their role orientation in the localization process of 
social service, the Western theory cannot apply, right position can understand how to do things and what to do, which is the key elements of social organization obtaining government trust; secondly, another key factor in the establishment of mutual trust between government and social organizations in the process of government purchase of services is the effect problem of social services provided by social organizations, if social organizations can provide professional services with high quality and efficiency, and social services have obvious effect, then trust the government for the social organization must be improved, there is no other choice, left to the social organization only to do everything, so that the trust of the government is changed into a real existence.

\section{Acknowledgements}

Fund project: this paper is humanity and social science research youth fund projects of Ministry of Education in 2014: "government purchase of public services: operating mechanism and practice problem" (14YJC630134); South China University of Technology operating expense key projects in central colleges and universities basic scientific research in 2015: " one of the phased achievements for the survival and development research of social work institutions under government purchases of services (2015ZDXM16).

\section{References}

[1]. Xu Yongxiang. Social reorganization: important topic of social management and social service at this stage [J], Teaching and Research, 2008 (1).

[2]. Lv Na, Zhang Peiguo. Strategic construction of relationships between government and society in public service purchase [J], Social Scientist, 2012 (6).

[3]. Gu Jiangxia. The power operation logic in government purchases of service contract B, based on social services research in B city in Pearl River Delta[J], Journal of Guangdong University of Technology(Social Sciences Edition), 2013 (4).

[4]. Xu Xuanguo, Yang Jun, Xu Yongxiang. The theoretical spectrum and transcendence of the government purchases of public services- new institutionalism as analysis perspective[J], Study and Practice, 2014 (10).

[5]. Xu Jialiang, Zhao Ting. The dilemma and path innovation of government purchases of public services [J], Chinese Public Administration, 2013 (8).

[6]. Zhao Huan, Yan Junfu, Xu Xuanguo. The logical starting point of government purchases of public services social services and third party assessment mechanism innovation [J], Journal of East China University of Science and Technology (Social Sciences Edition, 2014 (3).

[7]. Yu Keping. Administration and good governance, a new kind of political analysis framework [J], Social Sciences in Nanjing, 2001 (9).

[8]. Han Junkui. The comparison of current China's non-government organization participating in government purchases of services models[J], Comparative Economic \& Social Systems, 2009 (6).

[9]. Zheng Sujin. The government purchases of public services, public welfare non-profit organization as important partners [J], Journal of Public Management, 2009 (6).

[10]. Kang Xiaoguang. The cooperation strategy of NGO and government [M], Beijing: Social Sciences Academic Press, 2010. 